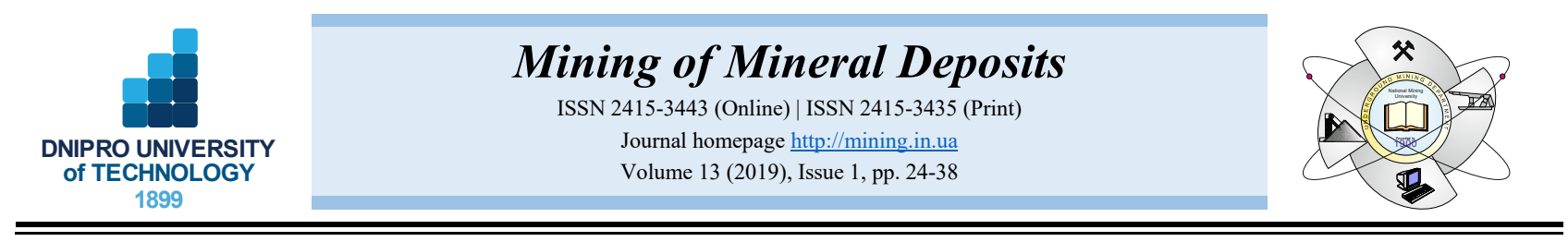

UDC 622.013:553.041

https://doi.org/10.33271/mining13.01.024

\title{
REVIEW OF MAN-MADE MINERAL FORMATIONS ACCUMULATION AND PROSPECTS OF THEIR DEVELOPING IN MINING INDUSTRIAL REGIONS IN UKRAINE
}

\author{
M. Petlovanyi ${ }^{1 *}$, O. Kuzmenko ${ }^{1}$, V. Lozynskyi ${ }^{1}$, V. Popovych ${ }^{2}$, K. Sai ${ }^{1}$, P. Saik ${ }^{1}$ \\ ${ }^{1}$ Dnipro University of Technology, Dnipro, Ukraine \\ ${ }^{2}$ Lviv State University of Life Safety, Lviv, Ukraine \\ *Corresponding author: e-mail petlyovany@ukr.net, tel. +380963194577
}

\begin{abstract}
Purpose. Analysis of the man-made mineral formations of ore mining and smelting, fuel and energy complexes development accumulation, location and prospects amount in the Dnipropetrovsk region.

Methods. Comprehensive approach, including analysis of state statistics, waste handling sites (WHSs), regional environmental report, environmental passport of the region, as well as data from other information sources is used in the work. Aerial photographs of man-made formations were obtained using the Google Earth 7.1.8 satellite program.

Findings. The analysis of the main man-made mineral formations of ore mining and smelting, fuel and energy complexes accumulation in Ukraine (coal and mining industry waste heaps, tailing dumps, ash dumps, smelter slag dumps) was conducted, their amount and occupied areas were estimated. According to the densest location of man-made formations, they are divided into 4 regions: the Prydniprovsk region, the Kryvyi Rih region, the Nikopol region, the Pavlohrad region. According to information sources, the content of some valuable components in man-made formations has been established. Based on the world market prices of technogenic deposits components research, it was proposed to grade them according to the cost of valuable components. The promising directions have been proposed for the use of mineral resources in various economic sectors. It is noted that from the perspective of development of mineral and raw materials potential, the bulk formations are of interest because of their large reserves in the minimum area. But from the perspective of environmental protection and the interests of the Ukrainian people, the bulk technogenic formations occupying significant areas of agricultural land and having smaller mineral reserves are of great interest.
\end{abstract}

Originality. The conception of man-made raw material mineral fund for further industrial development as an alternative to natural deposits is extended and systematized. For the first time, an integrated and detailed analysis has been performed of technogenic waste of the largest waste storage region in Ukraine, as well as the grouping has been proposed of mining and energy sector waste by density of location and by the contained components value.

Practical implications. A sketch-map of the man-made objects location was drawn up and their gradation was carried out according to the preliminary prospects of their development. This will provide a more objective approach to the concept of industrial waste development and planning the strategy for the development of mineral and raw materials potential both at the state and regional levels.

Keywords: man-made waste formations and deposits, waste heaps, tailing dumps, ash dumps, smelter slag dumps, commercial exploitation, gradation

\section{INTRODUCTION}

Significant components of the Ukrainian economy is the stable functioning of ore mining and smelting, fuel and energy complex, which form the country's main financial resources. In the process of the engineering and manufacturing cycle, $0.3-0.5$ billion tons of mineral and raw waste are generated annually at mining, concentrating, processing and energy enterprises (Haibin \& Zhenling, 2010; Gorova,
Pavlychenko, Kulyna, \& Shkremetko, 2012; Chetveryk, Bubnova, Babii, Shevchenko, \& Moldabaev, 2018). The production wastes accumulated as a result of ore mining and smelting, fuel and energy enterprises activity are sources of valuable mineral and raw materials. The problem of industrial waste accumulation from the functioning of mining and energy sector enterprises, the disposal of which is low $(25-30 \%)$, significantly damages the environment (Krook, Svensson, \& Eklund, 2012; Bini, Maleci, \& Wahsha, 2017;

(C) 2019. M. Petlovanyi, O. Kuzmenko, V. Lozynskyi, V. Popovych, K. Sai, P. Saik. (2019). Published by the Dnipro University of Technology on behalf of Mining of Mineral Deposits. This is an Open Access article distributed under the terms of the Creative Commons Attribution License (http://creativecommons.org/licenses/by/4.0/), which permits unrestricted reuse, distribution, and reproduction in any medium, provided the original work is properly cited. 
Popovych, Kuzmenko, Voloshchyshyn, \& Petlovanyi, 2018). However, despite this problem, being the result of the activities of the enterprises of fuel-power and miningmetallurgical complexes, the accumulated production wastes are sources of valuable mineral and raw resources (Shaw, Petavratzi, \& Bloodworth, 2013; Evdokimov, Maslakov, \& Evdokimov, 2016; Lèbre, Corder, \& Golev, 2017; Kendzera, \& Semenova, 2018).

An analysis of the ore stock depletion, extracted by traditional methods, shows that their reserves are being exhausted, while a significant part is lost in the earth's depths as inevitable losses. Therefore, in the long term it is necessary to forecast alternative raw materials for natural mineral reserves, in order to develop leading spheres of the national economy. The problem can be solved by involving resources of man-made mineral formation of ore mining and smelting, fuel and energy complexes in the development located on the mining regions territories which accumulation volumes have reached critical values (Afum, Caverson, \& Ben-Awuah, 2018; Kasmaee, Tinti, \& Bruno, 2018; Zhang \& Xu, 2018).

In addition, the development of man-made mineral formation resources allows to solve the problem of a significant reduction of the influence on the environment and improve the economic and social situation of the mining regions. This paper represents an overview of the most important accumulations of technogenic wastes from the mining and energy sectors of Ukraine, and the questions are raised as on the prospects for their development, so how to use their resources in various economic sectors.

\section{GENERAL CHARACTERISTICS OF THE MINING WASTE ACCUMULATION}

The long-term enterprises operation in various sectors of the economy has led to the accumulation of more than 30 billion tons of industrial waste, and by various estimates, the occupied areas reach $160-180$ thousand hectares (Galetskiy \& Egorova, 2008). In Ukraine, due to the imperfection of the methodological, technological, legal, environmental and economic aspects of industrial wastes handling, their wide development has not been spread. The lack of information on the valuable components content in man-made mineral formations does not allow us to determine the directions of their use and potential consumers of raw materials in both the public and private sectors. Therefore, the rational use of man-made mineral formations resources will gradually reduce primary mineral resources extraction, as well as prevent dispossession and contamination of significant areas.

According to the national report on the environmental conditions in 2015 (Natsionalna dopovid..., 2014), the bulk of the accumulated industrial waste of all hazard classes is concentrated in the main industrial areas Dnipro, Donetsk, Kropyvnytskyi, Luhansk, Lviv and Zaporizhiia (Fig. 1). The accumulation of man-made wastes across Ukraine is uneven, due to the location of the main industrial interprises in the central, southern and eastern parts of Ukraine, so $96 \%$ of all waste is concentrated there.

The mining industry of Ukraine is the leader in waste accumulation, accounting for more than $70 \%$ of all industrial waste generated annually. (a)

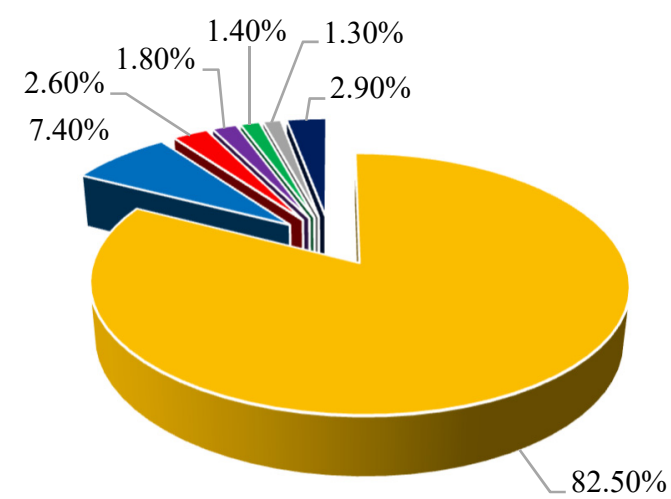

$\begin{array}{ll}\text { - Dnipropetrovsk region } & \text { - Donetsk region } \\ \text { - Kirovohrad region } & \text { - Lviv region } \\ \text { - Luhansk region } & \text { - Zaporizhzhia region } \\ \text { - Other } & \end{array}$

(b)

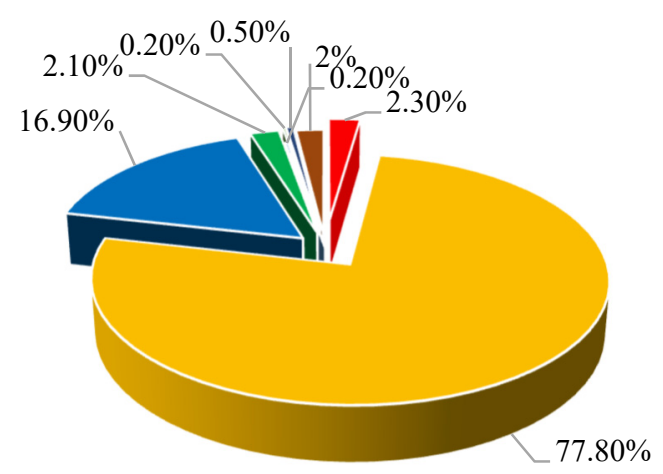

- Agriculture, forestry and fisheries

- Mining industry

- Supply of electrical power, gas and air conditioning

- Processing industry

- Building

- Transport, warehousing

- Other economic activities

- Households

Figure 1. Distribution of waste by region (a) and type of economic activity (b)

Over the past 10 years, the dynamics of waste generation in Ukraine has more than doubled (State Statistics..., 2019). At the same time, there were marked declines in the volume of accumulation (the period of the global crisis of $2008-2009)$, when the production volumes of all industrial enterprises declined (Fig. 2), and intensive increase in the period of $2010-2013$.

Mining and processing industrial man-made waste is distinguished from natural one by the following features (Frolova, 2007):

- geographically located in industrialized areas with existing infrastructure, which promotes their rapid development and use, and absence of exploration to detect them;

- are located on the earth's surface, which ensures more favorable and constant mining conditions of exploitation, independent on the development depth, and the mountain mass in them has already been crushed; 
- significantly more minerals (more than 30000) than in conventional fields (about 3000), which increases the requirements for development and processing schemes.

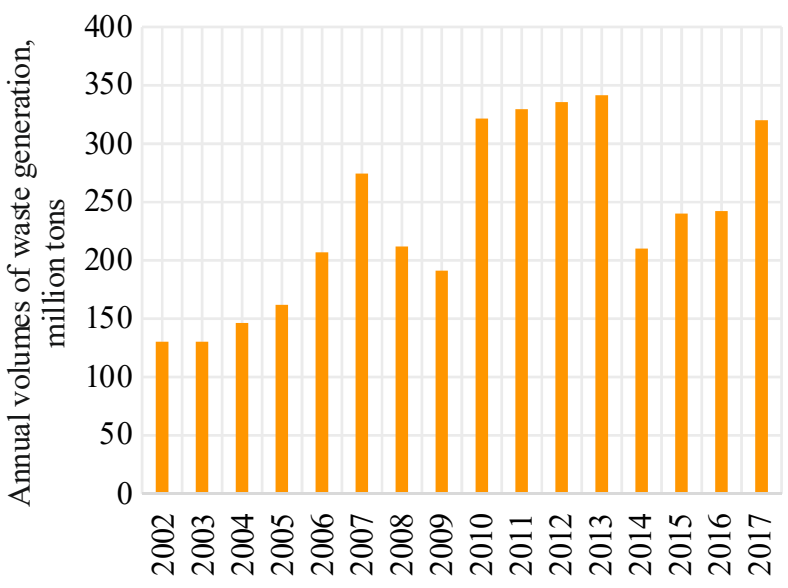

Figure 2. Dynamics of waste accumulation in the mining and processing industry of Ukraine

These features undoubtedly allow us to assert about the prospect of man-made wastes development, but at the same time, it is required to conduct a complex of scientific researches to study their qualitative and quantitative indicators and allocate perspective objects to the prior development. Foreign experience shows that the estimation and development of technogenic deposits in comparison with natural ores deposits cost less by $5-15$ times (Bol'shakov, Vasilenko, \& Galetskiy, 2009).

Comprehensive industrial development of man-made mineral formations is possible only after receiving the status of "Technogenic deposit", their reserves must be evaluated and have industrial significance. Due to the lack of financing for large-scale geological and economic assessments of man-made wastes, these accumulations only potentially belong to promising ones. There are real gaps in the legislative framework of Ukraine that lead to a slowdown in the man-made wastes industrial development process, which include the uncertainty of a specific waste owner, the lack of necessity for using man-made wastes part by industrial enterprises, and the lack of state support programs for owners on the technogenic deposits development (Prosandieiev, 2013; Hladii, 2017). Therefore, to stimulate enterprises to develop man-made waste, changes at the legislative level are needed.
On the territory of the Dnipropetrovsk region, 5 of 12 technogenic deposits in Ukraine have been registered: "Valiavkinske" tailing dump, "Kruta" gill (Western section), "Kruta" gill (Eastern section), the coal-bearing sludge deposit of the Dniprovskyi metallurgical complex, washinghouse sludge dump im. Maksymova, with some of them partially developed. However, in addition to the "technogenic deposits" in the region, there is a significant accumulation of man-made mineral formations of industrial enterprises that do not have this status, but in the near future they may be well subjected to industrial development.

In order to disclose and present the mineral and raw materials potential of man-made mineral formations and deposits, it is first of all necessary to identify these objects, to conduct a comprehensive analysis of the accumulation volumes, their location, useful components content, and on the basis of these data to formulate prospects for their further industrial development. In this article, based on a comprehensive analysis, the main man-made mineral formations containing valuable substances have been established and in the future they may well become the object of extraction.

Based on the volume of industrial waste distribution in the area of Ukraine, we pay attention to the Dnipropetrovsk region, which is the most representative waste storage region. Based on the generalization and comprehensive analysis of literature sources, public data on state statistics, waste handling sites, the national and regional environmental conditions report, the environmental passport of the Dnipropetrovsk region, and the data obtained as a result of carrying out personal scientific research, the main man-made mineral formations of ore mining and smelting, fuel and energy complexes were identified.

\section{THE MAIN MAN-MADE MINERAL FORMATIONS OF ORE MINING AND SMELTING, FUEL AND ENERGY COMPLEXES OF THE DNIPROPETROVSK REGION}

According to the conditions of the man-made mineral formations and deposits of ore mining and smelting, fuel and energy complexes (hereinafter OMSC and FEC), their classification (Vilkul, Azaryan, \& Kolosov, 2013) can be represented as follows (Fig. 3). Subsequently, the article deals with the different accumulated types of man-made formations in the Dnipropetrovsk region based on the study of the register of waste disposal sites for 2016 (Dnipropetrovsk regional state administration, 2019).

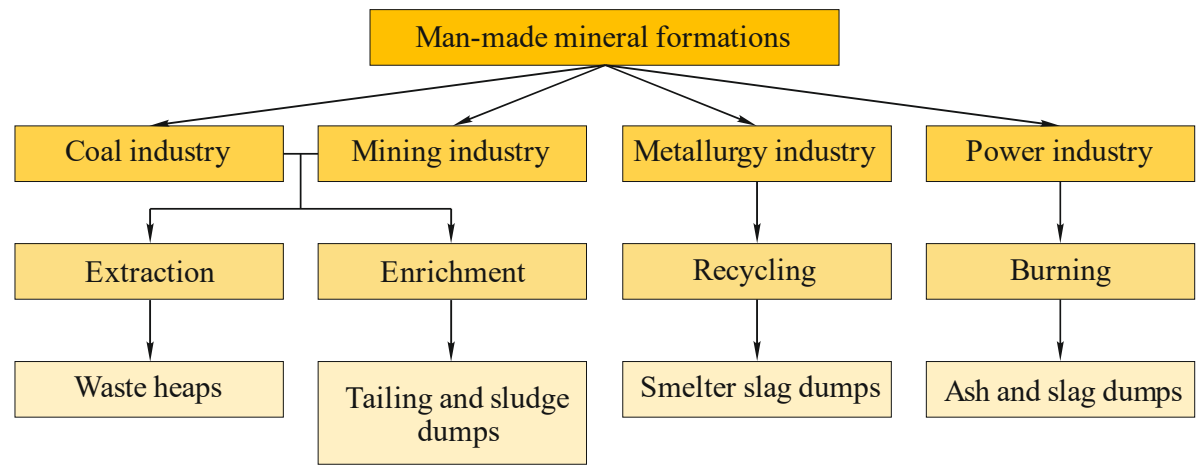

Figure 3. Classification of man-made mineral formations according to the development conditions 


\subsection{Waste heaps in coal industry}

The coal industry is the leading industry, since coal is the main energy source (Bondarenko, Griadushchiy, Dychkovskiy, Korz, \& Koval, 2007; Kuz'menko, Pochepov, \& Ryabychev, 2010). Since early 2014, the country's mining fund has suffered serious losses due to the temporary occupation of a significant area in the Donetsk and Luhansk region and conducting warfare, where there are more than 80 mines left. As of 2016, there are 55 operating mines in Ukraine, 32 of which are stateowned, and 29 are private (Petlovanyi, Lozynskyi, Saik, \& Sai, 2018). Donetsk, Dnipropetrovsk and Luhansk regions have a powerful mine fund, and Lviv and Volyn regions have smaller one. The main type of underground coal mining wastes is refuse heap (terricone). In Ukraine, there are 1200 waste heaps, more than 300 of which are burning, and most of the heaps are closed and recultivated.

The waste heap is a collection of rocks (siltstones, claystones, sandstones, shists) and coal fractions from the excavations that are stored in the special area. According to scientists, the amount of coal contained in the dump varies from 10 to $40 \%$. Analysis of the geometric parameters of more than 650 waste heaps of Ukrainian coal mines has made it possible to establish that the most common form is flat and conical ones (Bondarenko, Vivcharenko, \& Yarkovych, 2013).

In the Dnipropetrovsk region, the coal seams development (rank "gas flame") of the Western Donbass is carried out by the PJSC "DTEK Pavlohradvuhillia" coal companies, where there are 5 colliery groups, which consist of 2 mines. By 2016, mines produced 18.6 million tons of coal (Petlovanyi, Lozynskyi, Saik, \& Sai, 2018; Sotskov, Podvyhina, Dereviahina, \& Malashkevych, 2018). During the development of coal seams in the Western Donbass, 11 waste heaps have been accumulated. The coal content in the formed waste heaps reaches $2.6-12.0 \%$, sulfur $0.2-1.3 \%$, the shape of all the heaps is flat (Petlovanyi \& Medianyk, 2018). The gradation of PJSC "DTEK Pavlohradvuhillia" waste heaps in terms of the rock accumulation volume and occupied area is shown in Figure 4.

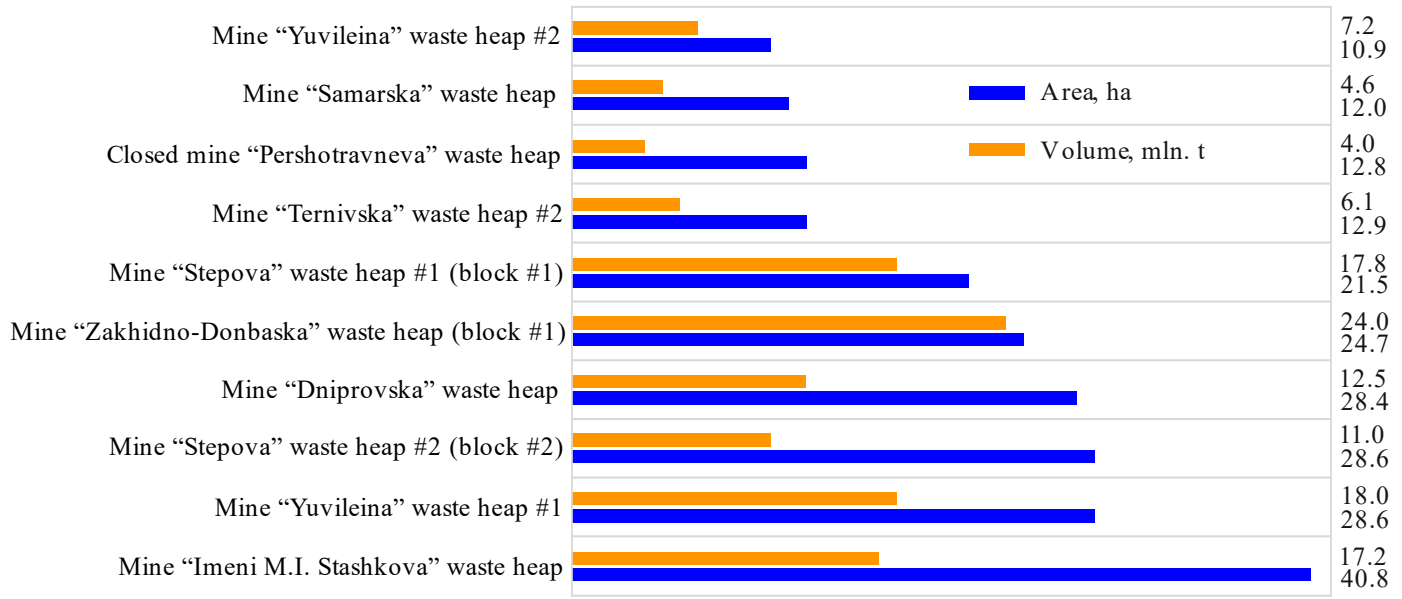

Figure 4. Waste heap gradation in terms of rock accumulation volume and occupied area

The analysis of Figure 4 allows us to state that the mines with greater capacity formed significant volumes of empty rocks $24-28$ million tons, while the planes under them reach $25-50$ hectares. One of the largest waste heaps in the occupied area belongs to the mine "Imeni M.I. Stashkova" (Fig. 5).

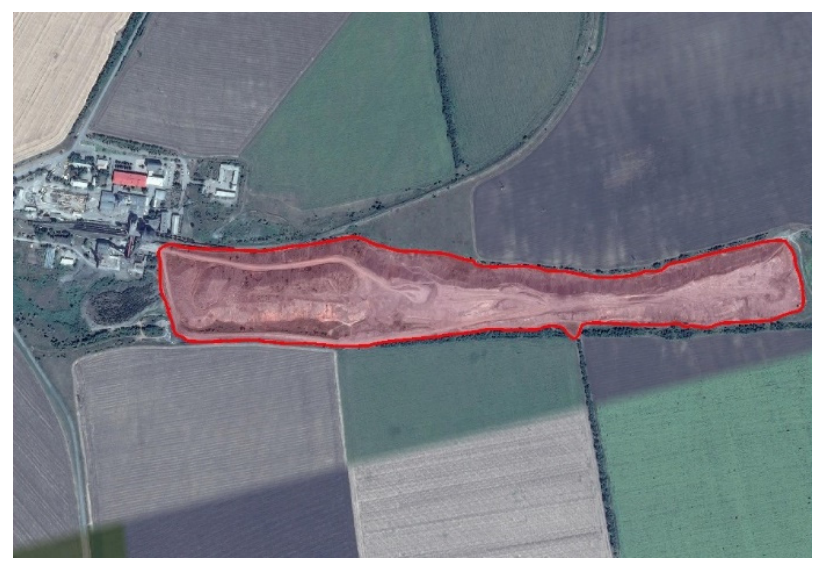

Figure 5. Mine “Imeni M.I. Stashkova” waste heap (area 40.8 hectares)
It should be noted that for flat dumps, a large area of land suitable for agricultural use in comparison with coneshaped dumps is allocated $5-7$ times. Therefore, from the position of environmental protection, the utilization of flat waste dumps is of high priority. The total number of accumulated empty rocks in mining sector is 122.4 million tons with an area of 221.2 hectares.

In addition to coal, a number of valuable rare earth elements are contained in empty dumps, the content of which may exceed their clarks in the earth's crust. The total content of valuable elements in the industrial sense from $10 \mathrm{~g} / \mathrm{t}$ in the dump is estimated in the range of 230 - $260 \mathrm{~g} / \mathrm{t}$, namely: scandium - up to $20 \mathrm{~g} / \mathrm{t}$, zirconium $20 \mathrm{~g} / \mathrm{t}$, germanium - up to $55 \mathrm{~g} / \mathrm{t}$, gallium - up to $100 \mathrm{~g} / \mathrm{t}$, yttrium - up to $25 \mathrm{~g} / \mathrm{t}$. In addition, in waste heaps, a significant amount of alum slate to $25 \%$ is contained in the oxide form and not less than $20 \%$ of iron (Zubova, 2004; Mnukhin, 2009).

According to the 10 operating mines of the Western Donbass, germanium reserves are estimated at 7375.5 tons in categories $\mathrm{C} 1+\mathrm{C} 2$. Germanium is not removed from coal and it is completely lost due to coal mining ( 86.9 tons) and losses (30.8 tons) (Rehionalna dopovid..., 2016a). 
In the mining of waste rock, the waste of underground mining is also used as a backfilling material when filling out the worked out spaces (Kuzmenko, Petlyovanyy, \& Heylo, 2014; Malashkevych, Sotskov, Medyanyk, \& Prykhodchenko, 2018) or processed into fuel due to the high content of combustible components (Lozynskyi et al., 2018; Saik, Petlovanyi, Lozynskyi, Sai, \& Merzlikin, 2018).

\subsection{Waste heaps of the mining industry}

A significant component of the ore mining industry of Ukraine except coal is mining industry. The iron ore extraction, iron ore concentrate production and metal export is the largest source of foreign exchange earnings to the state budget. More than $65 \%$ of the iron ore balance reserves are concentrated in Kryvyi Rih iron ore basin, where the main part of it is mined both in open and underground ways (Peregudov, Gritsina, \& Dragun, 2010; Chetverik, Babiy, \& Bubnova, 2013; Streltsov, Evtekhov, \& Evtekhova, 2017; Anisimov, Symonenko, Cherniaiev, \& Shustov, 2018). The main waste of iron ores extraction are dumps of uncovering open-pit and mining. The annual accumulation of empty iron ore rocks exceeds the volume of the coal industry, since the density of empty rocks is $1.4-1.5$ times higher than the density of rocks in the coal-bearing strata. The deposited rocks contain a number of valuable components, primarily iron, which content varies at the level of $15-25 \%$. The iron content in the rocks, and accordingly in the waste dumps, depends on the geological structure of the ore deposits and the morphological composition of enclosing rocks, which are extracted during mining (Petlovanyi, Lozynskyi, Zubko, Saik, \& Sai, 2019).

As a result of the plant's activity, 3 iron ore mining waste heaps are formed, close to each other. The waste heap gradation of the mining industry in terms of rocks accumulation volume and occupied area is shown in Figure 6.

Within Kryvyi Rih, where the largest mining capacities operate in Ukraine, the largest empty rocks concentration is observed (Fig. 7a). The largest share of raw ore in open method is produced by Metinvest "Central Mining and Processing Plant" (2 open-pits), Metinvest "North Ore Mining and Processing Plant" (2 open-pits) and PJSC "Southern Mining Factory".

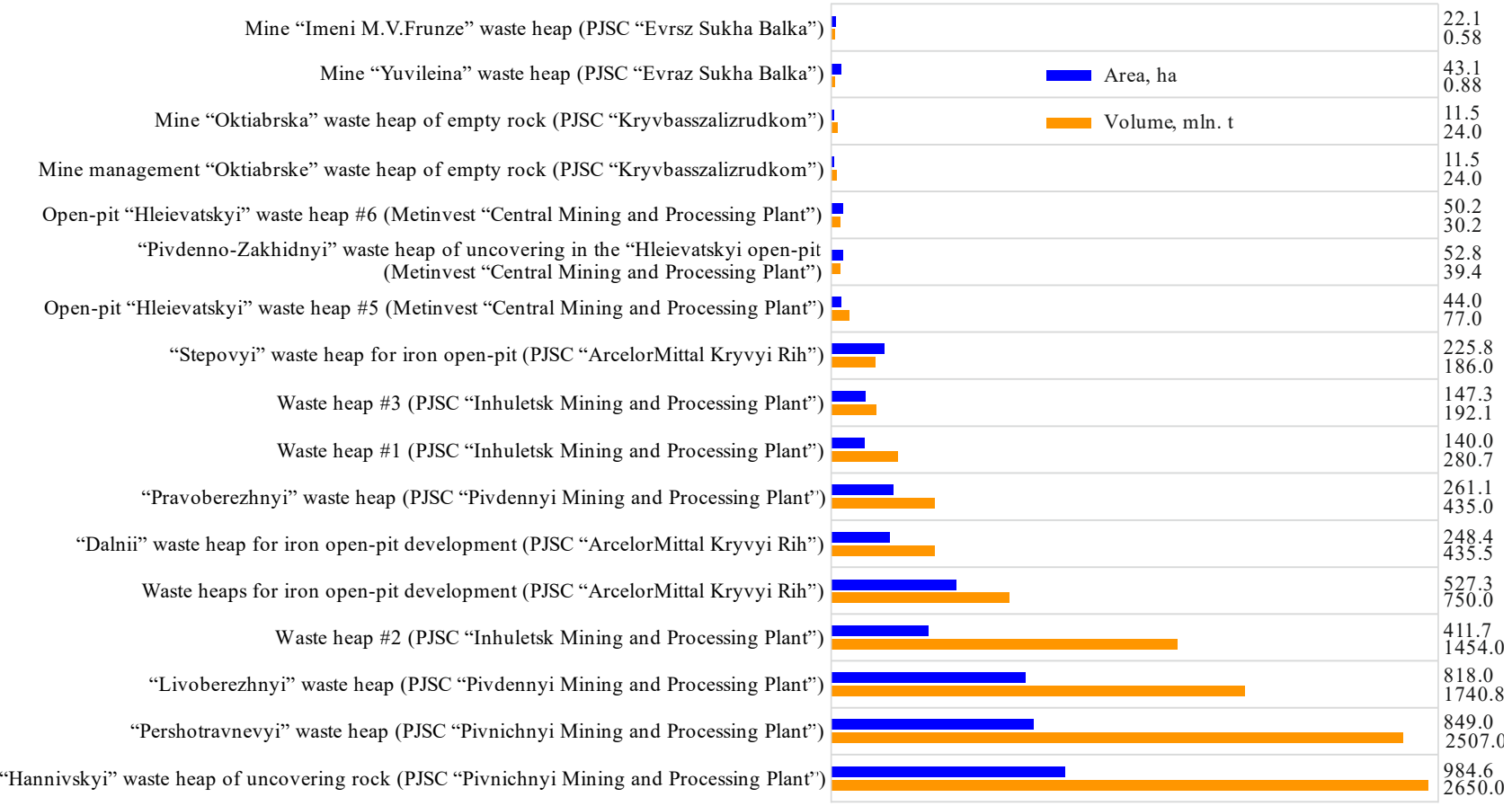

Figure 6. Gradation of dumps in terms of stored rocks volume and occupied area

(a)

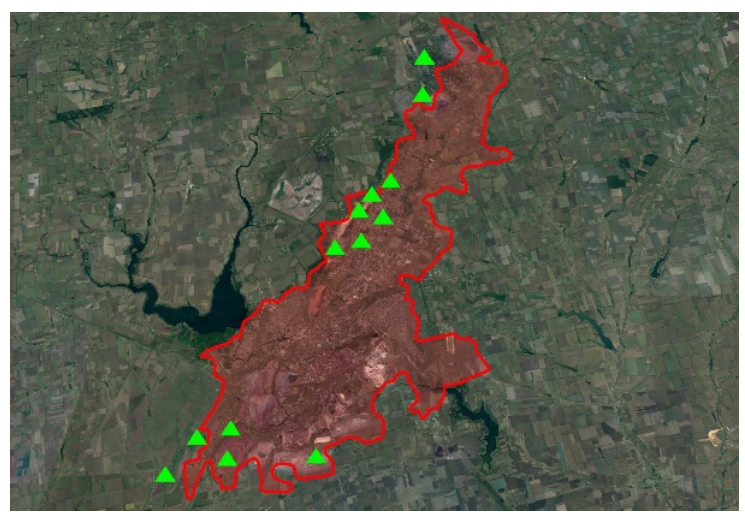

(b)

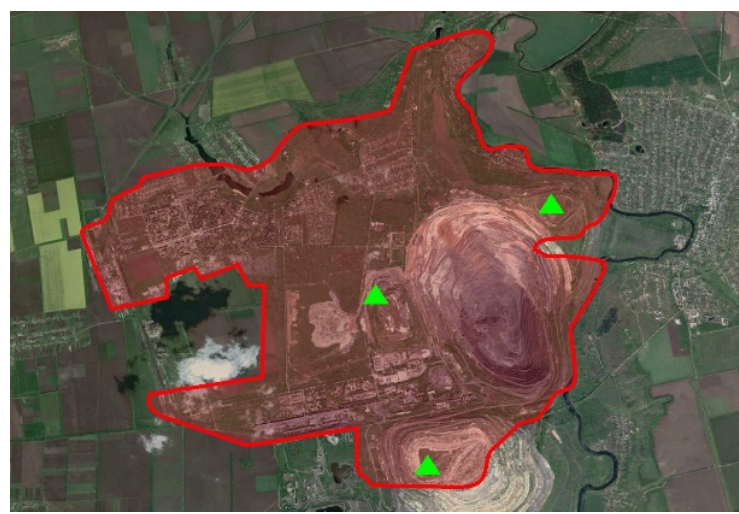

Figure 7. A detailed view of man-made empty rock accumulations in Kryvyi Rih (a) and Inhuletsk (b) 
As a result of the enterprises activities, up to 100 million tons of empty rocks are stored annually, which makes the ecological situation in the region difficult, and the present level of rocks utilization is not capable of reducing these volumes. The enterprises PJSC "Kryvbasszalizrudkom" (mines "Hvardiiska", "Rodina", "Oktiabrska", "Ternivska"); PJSC "ArcelorMittal Kryvyi Rih" (mine "Imeni Artoma"); PJSC "Evraz Sukha Balka" (mines "Yuvileina", "Imeni M.V. Frunze") and Metinvest Holding LLC (mine "Ordzhonikidze") extract iron ores in an underground way with a content of $40-61 \%$. The total annual mining production is 10.4 million tons. 30 kilometers south of Kryvyi Rih is the PJSC "Inhuletsk Mining and Processing Plant", part of the Metinvest Holding LLC (Fig. 7b).

The analysis of Figure 6 shows that the main contribution to the rocks accumulation in the Kryvyi Rih region is undoubtedly the open development (99\%), the dumps volumes fluctuate $0.14-2.60$ billion tons, and the areas occupied by them are $140-1000$ ha. The total number of accumulated empty ore mining sectors is 10.8 billion tons with an area of 4860 hectares. The lar-gest uncovering rocks dump in the Kryvyi Rih region is shown in Figure 8.

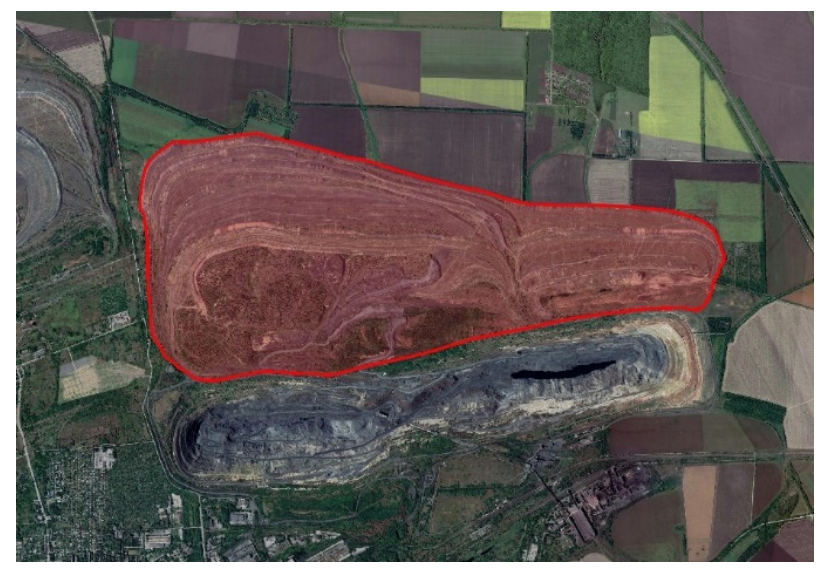

Figure 8. "Hannivskyi" waste heap of uncovering rock (PJSC "Pivnichnyi Mining and Processing Plant") (985 hectares)

\subsection{Tailing and sludge dumps}

After mineral extracting, the qualitative indicators of which do not satisfy the consumers' conditions, the next stage is the process of their enrichment to separate unproductive inclusions and increase the content of valuable components. In the Dnipropetrovsk region, iron, uranium, titanium-zirconium, manganese ores and coal are subjected to enrichment. In the process of enrichment, tailing dumps are inevitable, where wastes of mineral processing are stored.

The largest volumes of tailings were accumulated as a result of ferruginous quartzites enrichment in Kryvbas, with their annual $80-100$ million tons generation. To assess the distribution of iron directly in the tailing dumps of mining and processing plants (MPPs) and the calculation of reserves in the mid-1980s, geological exploration was carried out. At the tailing dump of Metinvest "Central Mining and Processing Plant", 56 wells were drilled along and across the central dredge piping dam to the entire depth of the tailing dump $(30 \mathrm{~m})$, and 20 wells along the other dams, that is unambiguously insufficient.
If we take into account that the average iron value in the tailing dumps is $12 \%$, only in Kryvbas 600 million tons of iron is accumulated with an annual replenishment of 60 million tons (Kopach \& Chilii, 2012). Preliminary data on some tailings dumps of Kryvbas (PJSC "Inhuletsk Mining and Processing Plant", PJSC "Pivnichnyi Mining and Processing Plant") prove their gold content. Areas with a content of $0.3-1.8 \mathrm{~g} / \mathrm{t} \mathrm{Au}$ in single tails were found in individual tails, and in gravity concentrates of $7-15 \mathrm{~g} / \mathrm{t}$. Experimental works on extracting gold from stale tails will undoubtedly significantly draw on man-made legacy placers Ukrainian mining enterprises and potential investors (Bragin, 2000). The hydromechanical method of extracting the valuable components from the placer deposits is the promising one (Malanchuk, Moshynskyi, Korniienko, \& Malanchuk, 2018).

A number of other tailing dumps are also quite promising in terms of the valuable components content. So, for example, in the "Rozbery" gill mine "Nova" LLC "Vostok-Ruda" (near Zhovti Vody), while optimizing the enrichment scheme with a tail content of $20.2 \%$, it is possible to obtain an iron concentrate with a content of at least $65 \%$ with tai-lings storage volumes of 2.5 million tons (Hubina, Hubin, \& Yarosh, 2015), and the enrichment wash waters of the Public Company "Marhanets Mining and Processing Plant" and Public Company "Ordzhonikidze Mining and Processing Plant" contain from 10 to $18 \%$ of manganese in Nikopol manganese ores deposit (Nikolaienko, Yevtiekhov, Babets, Filenko, \& Petrukhin, 2012). In the tailings of the Branch Plant "Vilnohirsk Mining and Metallurgical Plant" (Public Company "United Mining and Chemical Company"), which is developing the Malyshevske alluvial titanium-zirconium deposit, 300 million tons of enrichment was accumulated by some estimates. There are practically no zircon, rutile, leucoxene and ilmenite in the tailings, but the content of disthene, sillimanite, staurolite, tourmaline is significant, since these minerals are extracted to a lesser extent du-ring enrichment (Belogay \& Zelikov, 2000). This technogenic deposit is operated on the basis of a special permit by the LLC "Nonferrous Metals".

In Ukraine, a paradoxical situation has developed: from mining to rolling, the mass fraction of iron in the waste increases, and at the last stage of the whole cycle (in the production of rolled products), a rolling scale with a mass fraction of iron $(67-72 \%)$ is formed. Technogenic iron-containing raw materials, in which the mass fraction of iron exceeds its concentration in rich iron ore $(56-60 \%)$ and ferrous concentrate, which is obtained in concentrating factories $(65-68 \%)$ (Paranko, Yevtiekhov, \& Sydorenko, 2007). After extraction, the valuable mine refuse components can be used as a component in the consolidating stowing or interbedding technology in order to fill the voids after ore mining (Khomenko, Kononenko, \& Petlovanyi, 2015; Sun, Wang, \& Hou, 2018), for example, in the mines of the Kryvyi Rih iron ore basin.

It follows from the foregoing that tailing dumps and sludge dumps of mining and metallurgical enterprises have a powerful resource potential and should be regarded as ferrous and non-ferrous metals reserves. The main enterprises that store tailings in the region are the 
Prydniprovsk Hydrometallurgical Plant, Branch Plant "Vilnohirsk Mining and Metallurgical Plant" (Public Company "United Mining and Chemical Company"), LLC "Vostok-Ruda", PJSC "Dniprovsk Coke Plant", PJSC “ArcelorMittal Kryvyi Rih", PJSC "Pivdennyi Mining and Processing Plant", PJSC "Pivnichnyi Mining and Processing Plant", PJSC "Inhuletsk Mining and Processing Plant", Metinvest "Central Mining and Processing Plant”, Public Company "Ordzhonikidze Mining and Processing Plant", Public Company "Marhanets Mining and Processing Plant", Processing Plant "Pavlohradska", Public Company "Prosiansk Mining and Processing Plant", LLC "Demurinsk Mining and Processing Plant", and their gradation by tailings accumulation volume and occupied area is shown in Figure 9.

The analysis of figure shows that the main contribution to the tailings accumulation is made by the iron ore extraction cycle in the Kryvyi Rih region, the volumes of stored tailings in the tailing dumps fluctuate from 0.2 to 1.0 billion tons, and the areas occupied by them are $170-1700$ hectares. The total accumulation of tailings according to the analysis is 4.5 billion tons with an area of 9650 hectares. The largest tailing dump in the Dnipropetrovsk region is shown in Figure 10.

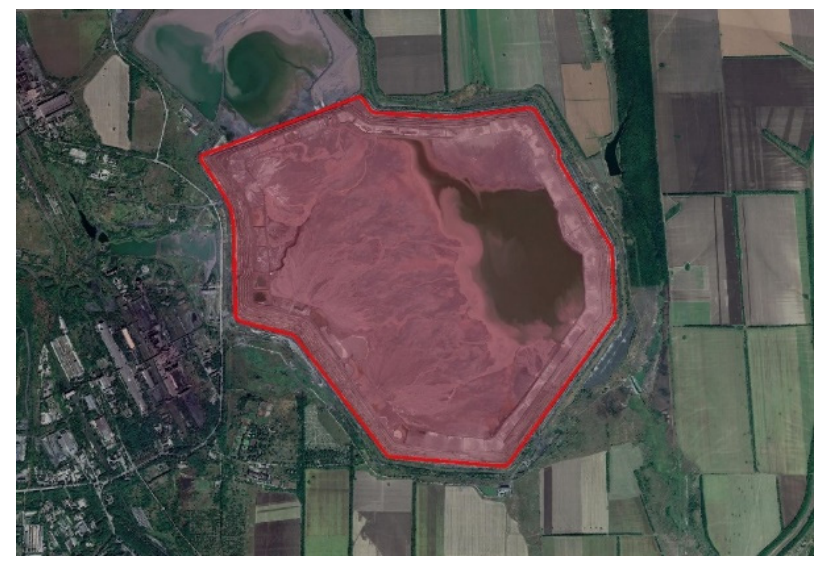

Figure 10. Tailing dump of Metinvest "Central Mining and Processing Plant” (1705 hectares)

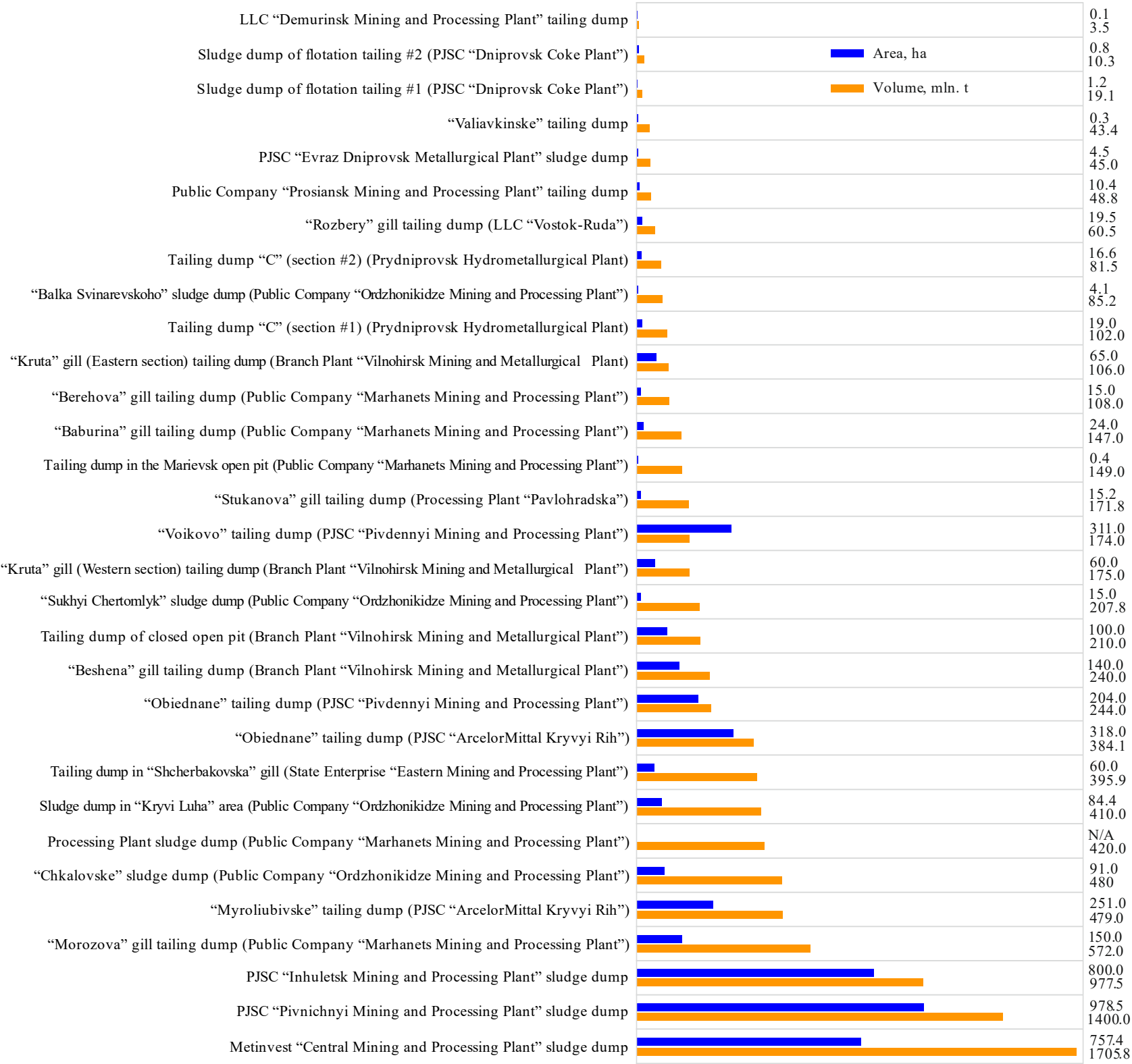

Figure 9. The gradation of tailing and sludge dumps by volume (a) and occupied area (b) 


\subsection{Ash and slag waste dump}

In the process of power generation by thermal power plants irreversible waste is ash and slag dust and tin dust, which with the help of pneumatic grinders and hydrosolar systems are stored in ash and slag dumps, to which significant areas of land are allocated. At present, almost all ash and slag waste dumps of thermal power plants (TPPs) are filled by $90-100 \%$, and expansion possibilities are not expected. In addition to the macroelements listed, which make up the bulk of the waste, ash and slag wastes contain microelements of such elements as zinc, thallium, lead, chromium, manganese, cobalt, nickel, mercury, arsenic, antimony, vanadium, strontium, germanium, boron, etc. (Prybylova, 2013; Kasimov, Udalov, \& Stalinskaya, 2016).

The bulk of ash and slag wastes $(96-98 \%)$ is the sum of oxides: silicon oxide $-45-60 \%$; calcium oxide $2.5-9.6 \%$; magnesium oxide $-0.5-4.8 \%$; iron oxide $4.1-10.6 \%$; aluminum oxide $-10.1-21.8 \%$ and sulfur trioxide $-0.03-2.7 \%$. Vanadium, which content is $0.04 \%$, and scandium $-0.002 \%$ are most valuable in ash and slag. Yttrium, nickel, germanium, chromium and titanium are considered as co-products. The flue ash in $\mathrm{Za}$ porizhzhya and Uglegors' $\mathrm{k}$ contains vanadium at $27 \%$ (Zhukovskiy, 2010; Oliinyk \& Prokopchuk, 2016).

Ash and slag wastes in Ukraine are generally considered to be waste, although in developed countries they are a valuable mineral raw material from which valuable components are extracted or used in the construction industry (Çiçek \& Çinçin, 2015). Howeverthe share of used wastes is very small - only $13-14 \%$ of the total yield, of which about $70 \%$ are used in construction and $30 \%$ in agriculture (Solovey, Vorob'yeva, \& Volovina, 2006). Annually, as a result of burning coal at the TPP, 14 million tons of ash and slag are accumulated, and this has a tendency to increase due to the deterioration of fuel quality (Galich, 2007).

The accumulation of ash and slag wastes depends on the location of 14 operating thermal power plants, 3 of which currently operate in the occupied territories, as well as a number of thermal power stations with ash and slag waste dumps. In the Dnipropetrovsk region there are 2 powerful thermal power plants: TPP in Kryvyi Rih (rank "fat"), Prydniprovsk TPP (rank "anthracite and "fat"), respectively, there are also ash and slag dumps. Their gradation by accumulation volume and occupied area is shown in Figure 11. The analysis of Figure 11 shows that according to the accumulation volume the Prydniprovsk TPP ash dump is the leader (71.4 million tons), and the TPP ash dump in Kryvyi Rih is in occupied area (429 hectares).

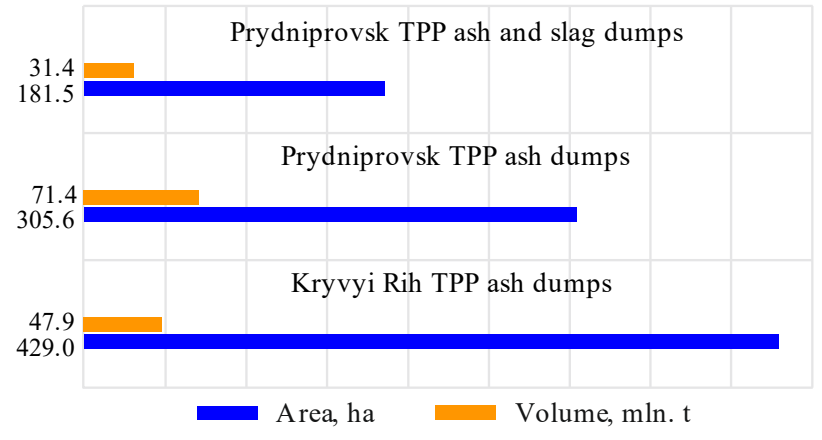

Figure 11. Ash and slag waste dump grading in terms of volume and occupied areas
The total tailings accumulation according to the analysis is 150.7 million tons with an area of 916.1 hectares. The largest ash and slag waste dumps in the Dnipropetrovsk region are shown in Figure 12.

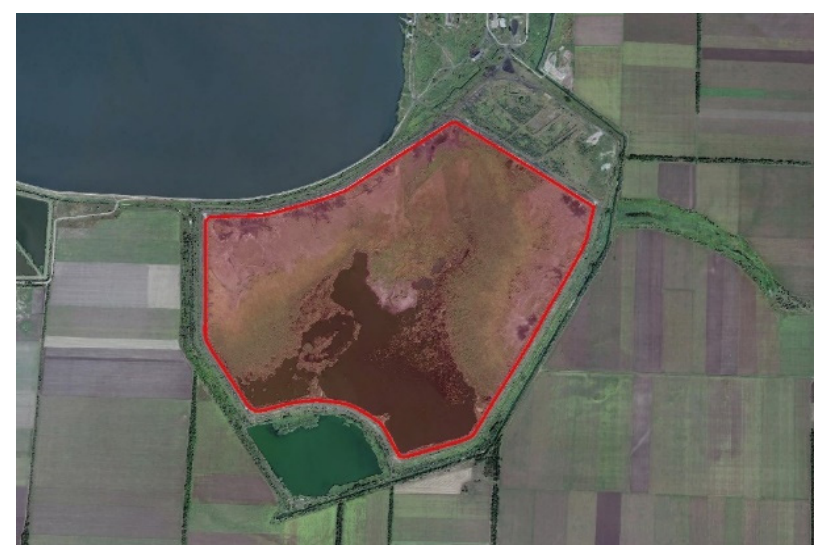

Figure 12. Ash dump in Kryvyi Rih TPP (429 hectares)

\subsection{Smelter slag dumps}

As a result of smelting ferrous and non-ferrous metals, as well as cast iron, the waste in the form of smelter slags is formed. Thus, the annual yield of smelter slags reaches: blast-furnace $-44 \%$, steel-smelting $-17 \%$, ferroalloy $15 \%$ of the production volumes of metals and alloys (Khobotova \& Kalmykova, 2012). Steelmaking slags with an iron content of more than $20 \%$ which amounts more than 100 million tons are accumulated in Ukraine, and about 300 million tons of blast-furnace slags with an iron content of $5-7 \%$. The task of slag utilization in connection with the environmental and economic problems growth is very relevant (Aleshin, Kazachkov, \& Ostroushko, 2007).

The granulated blast-furnace slags are mainly used in the cement industry for the manufacture of binders, since the chemical composition of the slag is close to Portland cement. Taking into account that slags are in a glassy state, they have an increased hydraulic activity, so they are granulated under rapid cooling by water, steam or air. The granulated blast-furnace slags are used: as a material for the manufacture of mixed hydraulic binders, as a component for the production of Portland cement, and also as an active mineral additive to Portland cement when it is milled; in the form of fillers in the manufacture of concrete, etc. (Rusina, 2007; Liu et al., 2017). In the mining industry, the milled slags often serve as the main binding substance for consolidating mixtures in order to fill underground voids (Kuz'menko, Petlyovanyy, \& Stupnik, 2013. For example, the granulated blast-furnace slags of PJSC "ArcelorMittal Kryvyi Rih" have a quality factor of 1.8, contain not less than $43 \% \mathrm{CaO}, 8.5 \% \mathrm{Al}_{2} \mathrm{O}_{3}$ and $38.5 \%$, and can be used as a substitute for Portland cement or serve as a separate binder. The level of the blast-furnace slags utilization reaches $60 \%$.

Metallurgical enterprises of Ukraine have accumulated experience in processing steelmaking slags with subsequent extraction of iron. Thus, at processing facilities AMCOM in the conditions of Metinvest "Azovstal Iron \& Steel Works" smelter slags are processed. In 2016, 0.29 million tons of slag were processed from 1.61 million tons of slag, and 1.32 million tons were placed at the waste handling sites of the enterprise (Rehionalna dopovid..., 2016b). 
The level of these slags utilization is in the range of $25-30 \%$. As a result of non-ferrous metals smelting, the slags of non-ferrous metallurgy are formed, but their utilization rate is $10-15 \%$. This is caused by the content of numerous rare and non-ferrous metals and impurities in them. The priority task is to extract the maximum amount of valuable components, with the subsequent use of slags as raw material in the construction industry (Khobotova \& Kalmykova, 2014).
The Dnipropetrovsk region is represented in metallurgy by such enterprises as PJSC "Evraz Dniprovsk Metallurgical Plant”, OJSC “Dniprovsk Metallurgical Plant”, PJSC "Interpipe Nyzhnodniprovskyi Tube Rolling Plant", Public Company "Nikopol Ferroalloy Plant", PJSC “ArcelorMittal Kryvyi Rih" that also contributes in slag waste accumulation. The slag dumps gradation in the region by accumulation volume and occupied area is shown in Figure 13.

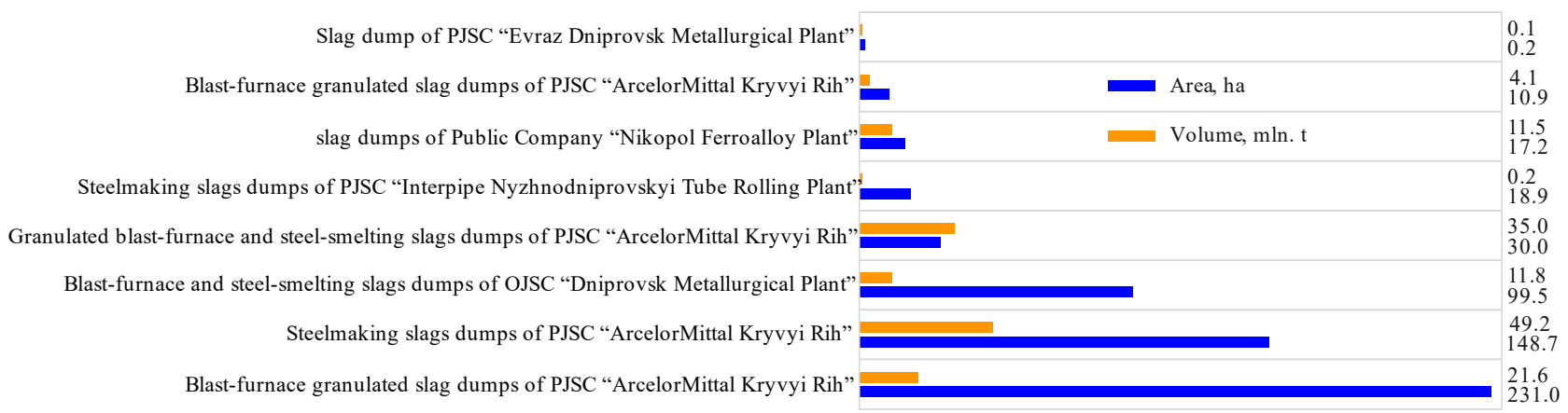

Figure 13. Smelter slag dumps gradation by volume and occupied area

The analysis of Figure 13 shows that the main contribution to the smelter slag dumps accumulation of the region is made by smelting of iron and steel. According to the volume of accumulation, the leader is PJSC "ArcelorMittal Kryvyi Rih", where 109.9 million tons of slags have been accumulated, and the enterprise occupies the leading position ( 420.6 hectares) in the area of dumps. The total slag accumulation in the region according to the analysis is 133.4 million tons with an area of 558 hectares. The largest smelter slag dump in the Dnipropetrovsk region is shown in Figure 14.

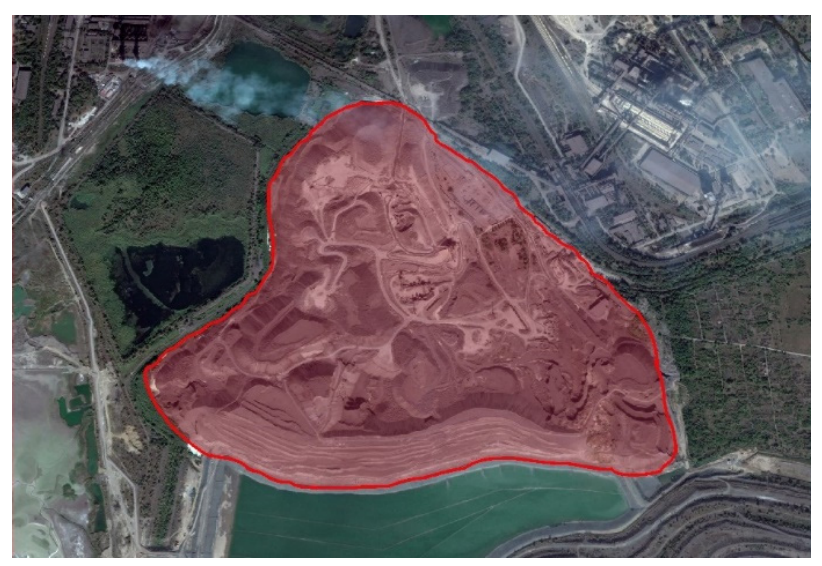

Figure 14. Steelmaking slags dumps of PJSC “ArcelorMittal Kryvyi Rih"

\section{PROSPECTS OF MAN-MADE MINERAL FORMATIONS OBJECTS COMMERCIAL DEVELOPMENT}

The feasibility of man-made mineral formations developing of ore mining and smelting, fuel and energy complexes is caused by the following peculiarities:

- valuable components extraction for additional realization or quality improvement of mining and processing enterprises production;
- valuable rare earth metals extraction;

- reducing the level of natural environment pollution;

- using rocks for construction purposes (roadfilling, mineral fillers);

- reducing environmental fees for production waste;

- creating new working positions operating in processing complexes infrastructure;

- returning lands in agriculture;

- the formation of new jobs, which would serve the infrastructure of processing plants.

However, the task of developing a technogenic waste should not be limited only by the extraction of valuable components. The industrial strategy should provide for the maximum possible reduction of waste volumes in different economic sectors, and the remaining volumes should be neutralized as much as possible in order to prevent a negative impact on the environment (Popovich, 2016; Lima, Mitchell, O'Connell, Verhoeven, \& Van Cappellen, 2016).

To stimulate the scientific and practical interest in the technogenic deposits development, they were zoned to different types of man-made mineral formations according to the density of their location (Fig. 15), and also scientific literature on valuable components content analysis was undertaken (Table 1).

It is proposed to distinguish 4 separate areas: Prydniprovsk (4 dumps of uncovering open-pit field in mining industry, 11 tailings and sludge dumps of iron, titanium-zirconium ore enrichment, 3 ash and slag dumps, 3 smelter slag dumps); Kryvyi Rih (16 dumps of mine and uncovering open-pit field in mining industry, 8 tailing dumps of iron ore enrichment, 1 ash and slag sludge, 5 smelter slag dumps); Nikopol (9 tailings and sludge dumps of manganese ore enrichment, 1 ferroalloy slags dump); Pavlohrad (11 waste heaps, 3 tailing dumps of coal, non-ferrous metals and kaolin enrichment).

The priority of the man-made formations development depends primarily on the commercial interest in the valuable elements contained in them and the relevance of their global market. 
Table 1. Valuable components content in man-made formations of different types

\begin{tabular}{|c|c|}
\hline $\begin{array}{l}\text { Man-made mineral } \\
\text { formation }\end{array}$ & $\begin{array}{l}\text { Valuable components content } \\
\text { (were found according to in- } \\
\text { formation sources) }\end{array}$ \\
\hline $\begin{array}{l}\text { Waste heaps } \\
\text { of the coal industry }\end{array}$ & $\begin{array}{c}\mathrm{Coal}-10 \%, \mathrm{Ge}-55 \mathrm{~g} / \mathrm{t} \\
\mathrm{Ga}-100 \mathrm{~g} / \mathrm{t} ; \mathrm{Sc}-20 \mathrm{~g} / \mathrm{t} \\
\mathrm{Fe}_{2} \mathrm{O}_{3}-15 \% ; \mathrm{Al}_{2} \mathrm{O}_{3}-15 \%\end{array}$ \\
\hline $\begin{array}{l}\text { Waste heaps } \\
\text { of mining industry }\end{array}$ & $\mathrm{Fe}_{2} \mathrm{O}_{3}-10 \%$ \\
\hline $\begin{array}{l}\text { Iron ore waste } \\
\text { tailings dumps }\end{array}$ & $\begin{array}{c}\mathrm{Fe}_{2} \mathrm{O}_{3}-12 \% ; \mathrm{Ag}-3 \mathrm{~g} / \mathrm{t} \\
\mathrm{Au}-1 \mathrm{~g} / \mathrm{t} ; \mathrm{V}-140 \mathrm{~g} / \mathrm{t} \\
\mathrm{W}-5 \mathrm{~g} / \mathrm{t} ; \mathrm{Ge}-10 \mathrm{~g} / \mathrm{t}\end{array}$ \\
\hline $\begin{array}{l}\text { Uranium ore waste } \\
\text { tailings dumps }\end{array}$ & $\mathrm{U}-0.017-0.023 \%$ \\
\hline $\begin{array}{l}\text { Manganese ore waste } \\
\text { tailings dumps }\end{array}$ & $\begin{array}{c}\mathrm{MnO}-15 \% ; \mathrm{Fe}_{2} \mathrm{O}_{3}-5.3 \% \\
\mathrm{Al}_{2} \mathrm{O}_{3}-8 \%\end{array}$ \\
\hline $\begin{array}{l}\text { Coal enrichment } \\
\text { tailings dumps }\end{array}$ & Coal fractions $15-20 \%$ \\
\hline $\begin{array}{l}\text { Ash and slag } \\
\text { waste dumps }\end{array}$ & $\begin{array}{c}\mathrm{Al}_{2} \mathrm{O}_{3}-22.2 \% ; \mathrm{Fe}_{2} \mathrm{O}_{3}-11.5 \% \\
\mathrm{TiO}_{2}-1.08 \% ; \mathrm{Cr}-0.001 \% \\
\mathrm{~V}-0.03 \% ; \mathrm{Sc}-0.003 \% \\
\mathrm{Zr}-0.01 \%\end{array}$ \\
\hline Smelter slag dumps & $\begin{array}{c}\mathrm{FeO}-14 \% ; \mathrm{Al}_{2} \mathrm{O}_{3}-7 \% \\
\mathrm{Cr}_{2} \mathrm{O}_{3}-1.5 \% ; \mathrm{MnO}-0.9 \% \\
\mathrm{TiO}_{2}-0.4 \%\end{array}$ \\
\hline
\end{tabular}

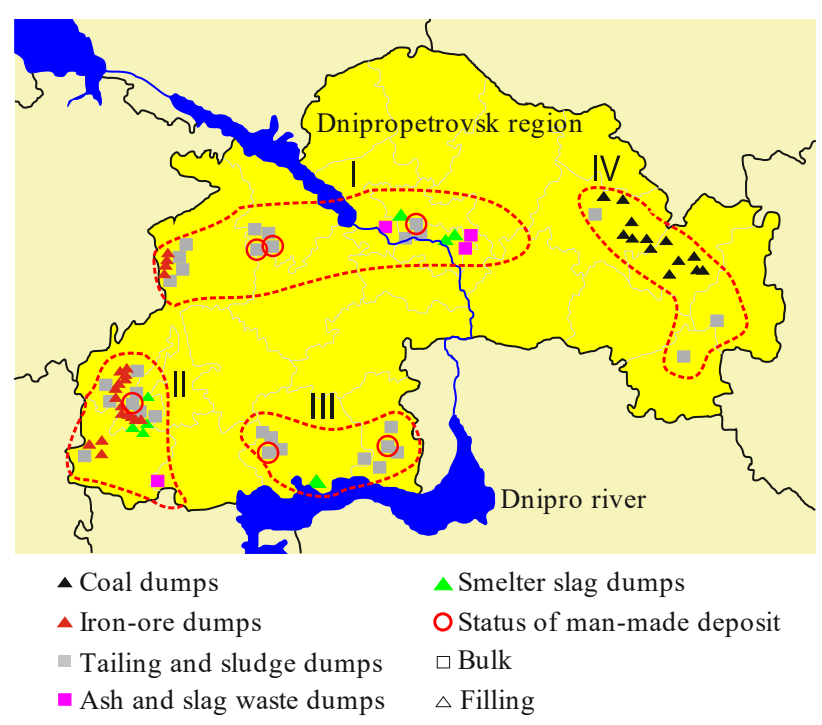

Figure 15. The layout of the main man-made thermal power plants and mining and metallurgical plant structures

According to the information sources analysis of world markets, including the London Metal Exchange, on valuable components found in man-made formations, made it possible to estimate their possible cost in 1 ton of waste, which is presented in Table 2 (data for the end of 2016) (Infogeo, 2019).

It is also proposed to zone the man-made mineral formations in the Dnipropetrovsk region according to the approximate cost estimate, which in a way characterizes the prospects of their development. The criterion of zoning can be the cost of known valuable components in pure form, contained in 1 ton of man-made formations. 1 ton of waste in cash equivalent is provided an estimate according to the established valuable components content, information sources data (Table 1) and its value (Table 2).
Table 2. Forecasted cost of valuable components in man-made mineral formations

\begin{tabular}{cc}
\hline $\begin{array}{c}\text { Valuable } \\
\text { component }\end{array}$ & $\begin{array}{c}\text { Market cost of valuable elements, } \$ / t \\
\text { (according to information sources) }\end{array}$ \\
\hline $\mathrm{Ge}$ & 900000 \\
$\mathrm{Ga}$ & 145000 \\
$\mathrm{Sc}$ & 15000000 \\
$\mathrm{Fe}$ & 100 \\
$\mathrm{Al}$ & 1790.8 \\
$\mathrm{Au}$ & 42500000 \\
$\mathrm{~V}$ & 12000 \\
$\mathrm{Ni}$ & 9984 \\
$\mathrm{Ag}$ & 570400 \\
$\mathrm{Zn}$ & 2713 \\
$\mathrm{Cr}$ & 7650 \\
$\mathrm{Mn}$ & 2100 \\
$\mathrm{Ti}$ & 8000 \\
$\mathrm{U}$ & 25000 \\
$\mathrm{~W}$ & 32700 \\
$\mathrm{Zr}$ & 110000 \\
\hline
\end{tabular}

The analysis of the obtained results in providing an estimate of valuable components in waste allowed to separate the man-made mineral formations and deposits into 3 groups:

- group I - estimated cost of components in waste is more than $200 \$ / t$;

- group II - estimated cost of components in waste is within the limits of $100-200 \$ / t$;

- group III - estimated cost of components in waste is within the limits of $0-100 \$ / t$.

However, it is also necessary to consider the operating procedure cost of the valuable components extracting, due to the fact that, despite the maintenance of valuable components, the cost of their processing and extraction may be unprofitable.

The general scheme of man-made mineral formations and deposits gradation in the Dnipropetrovsk region on the estimated cost of valuable components per 1 ton of waste is given in Figure 16.

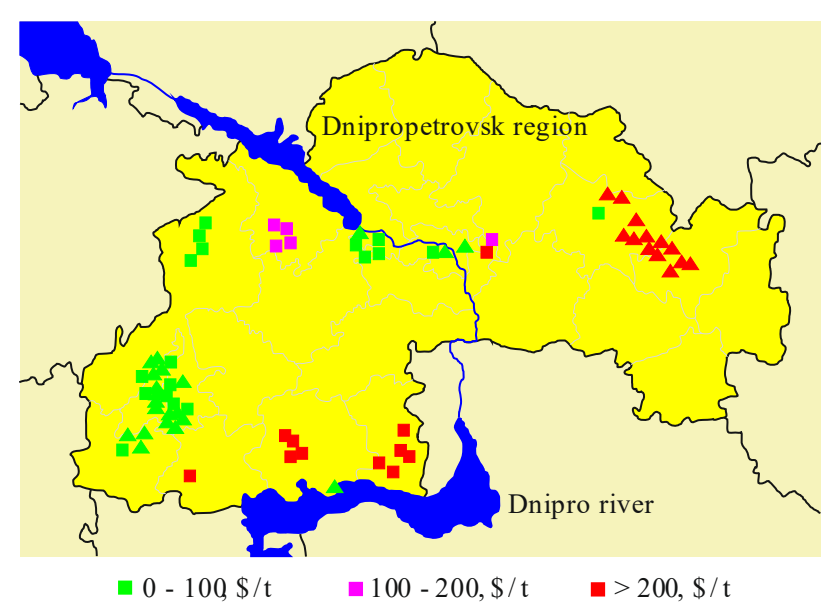

Figure 16. Man-made mineral formations and deposits gradation in the Dnipropetrovsk region on the estimated cost of valuable components per 1 ton of waste 
According to Figure 16 it is appropriate to develop Public Company "Marhanets Mining and Processing Plant" and Public Company "Ordzhonikidze Mining and Processing Plant" tailing dumps, Prydniprovsk TPP and Kryvyi Rih TPP ash dumps, waste heaps in the Western Donbass, Branch Plant "Vilnohirsk Mining and Metallurgical Plant" (Public Company "United Mining and Chemical Company") tailing dumps, Public Company "Nikopol Ferroalloy Plant" slag dumps at first-priority.

At present, there is a complexity of rare earth metals extraction from waste heaps in pure form, which is connected with the complex chain of technological processes and considerable cost of their processing. However, with the gradual development and improvement of treatment process, waste heaps are among the most promising for development. In addition to extracting valuable components, according to scientific data, manmade formations can serve as a valuable source of raw materials for various types of construction industry, significantly reducing the cost of building materials production in comparison with the extracted natural components. The main directions of man-made formations use and recycling are as follows (Table 3 ).

Table 3. Directions of man-made formations use and recycling

\begin{tabular}{|c|c|}
\hline $\begin{array}{l}\text { Man-made } \\
\text { formation }\end{array}$ & Directions of use \\
\hline $\begin{array}{l}\text { Waste heaps of } \\
\text { the mining and } \\
\text { coal industry }\end{array}$ & $\begin{array}{l}\text { Extraction of valuable components, pro- } \\
\text { duction of small and large aggregates in } \\
\text { light and heavy concrete and mortars, } \\
\text { ballast layer for the roadway platform } \\
\text { construction, use of rocks as additional } \\
\text { energy feedstock (gasification), use of } \\
\text { rocks as a fill material }\end{array}$ \\
\hline $\begin{array}{l}\text { Iron ore waste } \\
\text { tailing dumps }\end{array}$ & $\begin{array}{l}\text { Extraction of valuable components, pro- } \\
\text { duction of siliceous sand and breakstone } \\
\text { for construction materials and surfacing } \\
\text { the roadway platform, a component for } \\
\text { the preparation hydro- or hardening } \\
\text { backfill }\end{array}$ \\
\hline $\begin{array}{l}\text { Ash and slag } \\
\text { waste dumps }\end{array}$ & $\begin{array}{l}\text { Extraction of valuable components (in- } \\
\text { cluding microspheres), active mine-ral } \\
\text { admixture and small aggregate in light } \\
\text { and heavy concrete and artificial ce- } \\
\text { ment, analog for clay parts in the pro- } \\
\text { duction of cement clinker, production of } \\
\text { ceramic bricks, component for the prep- } \\
\text { aration of hardening backfill }\end{array}$ \\
\hline $\begin{array}{l}\text { Smelter slag } \\
\text { dumps }\end{array}$ & $\begin{array}{l}\text { production of valuable mineral powders } \\
\text { for asphalt-concrete, production of } \\
\text { ground slag for dry mortars, production } \\
\text { of slag and slag-lime cement, produc- } \\
\text { tion of slag stone, slag-lime concrete } \\
\text { and tiles, production of small and large } \\
\text { aggregate }\end{array}$ \\
\hline
\end{tabular}

\section{CONCLUSIONS}

In Ukraine, colossal volumes of man-made raw materials have been accumulated, which represents a powerful mineral-raw material potential for important sectors of the Ukrainian economy development. The technogenic deposits development at an appropriate level of scientific and technological progress and investments will allow competing with traditional methods of minerals development, the initial capital costs of which are significantly higher.
The complex analysis of the main identified man-made mineral formations accumulation showed that as a result of ore mining and smelting, fuel and energy enterprises activity in Dnipropetrovsk region it is accounted for 15.6 billion tons, which are distributed as follows: $69 \%-$ rocks of the mining industry; $0.64 \%$ - rocks of the coal industry; $28.9 \%$ - tailings and slags; $0.94 \%$ - ashes; $0.85 \%$ - smelter slags. The area occupied with man-made mineral formations is 11790 hectares, and the distribution according to their type is as follows: $3.9 \%$ - rocks of the mining industry; $1.75 \%$ - rocks of the coal industry; $81.85 \%$ - tailings and slags; $7.77 \%$ - ashes; $4.73 \%$ - smelter slags. Distribution by the man-made formations type (bulk, filling) are: 70.7 and $29.3 \%$ - by accumulation volume; 10.4 and $89.6 \%$, respectively, by the area of occupation. It follows that from the standpoint of mineral-raw material potential mastering, the bulk formations are of interest due to their large reserves at the minimum area, and from the point of view of the environment protection and Ukrainian people interests - filling man-made formations occupying large areas of agricultural land and having lower raw mineral reserves.

The gradation of man-made mineral formations and deposits in the Dnipropetrovsk region according to the estimated cost of valuable components found in 1 ton of waste is proposed. According to the preliminary estimate, the most attractive on value of components contain for industrial development are waste heaps of coal mines, tailings of titanium-zirconium and manganese ores enrichment, ash and slag wastes. The main areas of man-made wastes development should position the extraction of valuable components and raw materials for the construction industry.

A number of aspects and areas that will stimulate the industrial development of technogenic deposits in Ukraine should also be noted:

- analysis and development of the domestic and foreign markets;

- improvement of the legislative and normative base in the part of mining industry waste transferring to the status of technogenic deposit and the mechanism of legal relations between the state and the joint owners;

- attraction of foreign experts in technogenic deposits projects development;

- development of methodical apparatus for determining the priority objects of man-made formations for industrial development;

- formation of a database on modern technologies for the technogenic deposits processing, taking into account economic and environmental efficiency of the use;

- creation of a unified information base of technogenic deposits with fixing the main geographic, topographical, technological, qualitative and quantitative characteristics that will allow to supplement and expand the ideas about the general fund of mineral raw materials resources.

\section{ACKNOWLEDGEMENTS}

This work has been performed in the framework of tasks of a research project funded by the state budget by the Ministry of Education and Science of Ukraine (GP-500), and is also consistent with the "Dnipropetrovsk Regional Complex Program (Strategy) on Environmental Safety and Prevention of Climate Change for 2016 - 2025". 


\section{REFERENCES}

Afum, B.O., Caverson, D., \& Ben-Awuah, E. (2018). A conceptual framework for characterizing mineralized waste rocks as future resource. International Journal of Mining Science and Technology. https://doi.org/10.1016/j.ijmst.2018.07.002

Aleshin, A.A., Kazachkov, E.A., \& Ostroushko, A.V. (2007). Povyshenie effektivnosti pererabotki tverdykh metallurgicheskikh shlakov. Visnyk Pryazovskoho Derzhavnoho Tekhnichnoho Universytetu, (17), 220-223.

Anisimov, O., Symonenko, V., Cherniaiev, O., \& Shustov, O. (2018). Formation of safety conditions for development of deposits by open mining. E3S Web of Conferences, (60), 00016. https://doi.org/10.1051/e3sconf/20186000016

Belogay, P.D., \& Zelikov, M.A. (2000). Opyt osvoeniya technogennykh titano-tsirkonievykh rossypey Pridneprov'ya. Tekhnogennye Rossypi. Problemy. Resheniya, 132-136.

Bini, C., Maleci, L., \& Wahsha, M. (2017). Mine waste: assessment of environmental contamination and restoration. Assessment, Restoration and Reclamation of Mining Influenced Soils, 89-134. https://doi.org/10.1016/b978-0-12-809588-1.00004-9

Bol'shakov, V.I., Vasilenko, S.P., \& Galetskiy, L.S. (2009). Gorno-metallurgicheskiy kompleks Ukrainy (tsifry, fakty, kommentarii). Kyiv: Nauka.

Bondarenko, V., Griadushchiy, Y., Dychkovskiy, R. Korz, P., \& Koval, O. (2007). Advanced experience and direction of mining of thin coal seams in Ukraine. Technical, Technological and Economical Aspects of Thin-Seams Coal Mining, International Mining Forum, 2-7. https://doi.org/10.1201/noe0415436700.ch1

Bondarenko, V.I., Vivcharenko, A.V., \& Yarkovych, A.I. (2013). New technique of coal mining very thin seams with leaving rock in mine. Szkola Eksplotacji Podziemnej, 75-81.

Bragin, Yu.N. (2000). Tekhnogennye rossypi Fe-Mn mineralov v Ukraine. Tamzhe, 28-33.

Chetverik, M., Babiy, E., \& Bubnova, E. (2013). The main technical solutions in rational excavation of minerals in open-pit mining. Annual Scientific-Technical Collection - Mining of Mineral Deposits, 173-176. https://doi.org/10.1201/b16354-31

Chetveryk, M., Bubnova, O., Babii, K., Shevchenko, O., \& Moldabaev, S. (2018). Review of geomechanical problems of accumulation and reduction of mining industry wastes, and ways of their solution. Mining of Mineral Deposits, 12(4), 63-72.

https://doi.org/10.15407/mining12.04.063

Çiçek, T., \& Çinçin, Y. (2015). Use of fly ash in production of light-weight building bricks. Construction and Building $\mathrm{Ma}$ terials, (94), 521-527.

https://doi.org/10.1016/j.conbuildmat.2015.07.029

Dnipropetrovsk regional state administration. (2019). Retrieved from http://old.adm.dp.gov.ua/OBLADM/obldpeng.nsf/home.xsp

Evdokimov, S.I., Maslakov, M.P., \& Evdokimov, V.S. (2016). Construction materials based on wastes from mining and metallurgical industries. Procedia Engineering, (150), 1574-1581. https://doi.org/10.1016/i.proeng.2016.07.120

Frolova, Yu.K. (2007). Prichiny vozniknoveniya i perspektivy ispol'zovaniya tekhnogennykh mestorozhdeniy. Gornyy Informatsionno-Analiticheskiy Byulleten', (7), 24-32.

Galetskiy, L.S., \& Egorova, T.M. (2008). Regional'nyy ekologo-geokhimicheskiy analiz vliyaniya tyazhelykh metallov promyshlennykh otkhodov na sostoyanie okruzhayushchey sredy Ukrainy. Ekolohiia Dovkillia ta Bezpeka Zhyttiediialnosti, (5), 10-14

Galich, S.A. (2007). Perspektivy ispol'zovaniya zoloshlakov TES v kachestve mikroudobreniya dlya pochv. Sotrudnichestvo dlya Resheniya Problemy Otkhodov, 108-109.
Gorova, A., Pavlychenko, A., Kulyna, S., \& Shkremetko, O. (2012). Ecological problems of post-industrial mining areas. Geomechanical Processes During Underground Mining Proceedings of the School of Underground Mining, 35-40. https://doi.org/10.1201/b13157-7

Haibin, L., \& Zhenling, L. (2010). Recycling utilization patterns of coal mining waste in China. Resources, Conservation and Recycling, 54(12), 1331-1340.

https://doi.org/10.1016/j.resconrec.2010.05.005

Hladii, O.V. (2017). Pravove rehuliuvannia opodatkuvannia diialnosti, poviazanoi z vykorystanniam tekhnohennykh rodovyshch. Yurydychnyi Naukovyi Elektronnyi Zhurnal, (2), 64-66.

Hubina, V.H., Hubin, H.H., \& Yarosh, T.P. (2015). Pro rechovynnyi sklad chervonykh shlamiv. Visnyk Kryvorizkoho Tekhnichnoho Universytetu, (40), 78-83.

Infogeo.ru. (2019). Retrieved from: http://www.infogeo.ru

Kasimov, A. M., Udalov, I. V., \& Stalinskaya, I. V. (2016). Development of waste disposal effective technologies by power generating and chemical industries. Visnyk of V.N Karazin Kharkiv national university-series geology geography ecology, (45), 139-147.

Kasmaee, S., Tinti, F., \& Bruno, R. (2018). Characterization of metal grades in a stockpile of an Iron Mine (Case study Choghart iron mine, Iran). Rudarsko-Geološko-Naftni Zbornik, 33(2), 51-59. https://doi.org/10.17794/rgn.2018.2.5

Kendzera, O., \& Semenova, Y. (2018). The influence of the sedimentary strata on the seismic oscillation on the teritory Tashlyk hydroelectric pumped storage power plant. Geodynamics, 24(1), 91-99. https://doi.org/10.23939/jgd2018.01.091

Khobotova, E.B., \& Kalmykova, Yu.S. (2012). Sravnitel'nyy analiz khimiko-mineralogicheskogo sostava otval'nogo i granulirovannogo domennogo shlaka. Zbirnyk Naukovykh Prats PAT "UkrNDIVohnetryviv im. A.S. Berezhnogo", (112), 230-237.

Khobotova, E.B., \& Kalmykova, Yu.S. (2014). Zashchita okruzhayushchey prirodnoy sredy pri utilizatsii otval'nykh domennykh shlakov $v$ proizvodstve stroitel'nykh materialov. Kharkiv: KhNADU.

Khomenko, O., Kononenko, M., \& Petlovanyi, M. (2015). Analytical modeling of the backfill massif deformations around the chamber with mining depth increase. New Developments in Mining Engineering 2015: Theoretical and Practical Solutions of Mineral Resources Mining, 265-269. https://doi.org/10.1201/b19901-47

Kopach, P.I., \& Chilii, D.V. (2012). Analiz protsesiv vidkhodoutvorennia na vyrobnytstvakh hirnycho-metalurhiinoho rehionu. Ekolohiia i Pryrodokorystuvannia, (15), 118-132.

Krook, J., Svensson, N., \& Eklund, M. (2012). Landfill mining: a critical review of two decades of research. Waste Management, 32(3), 513-520. https://doi.org/10.1016/j.wasman.2011.10.015

Kuz'menko, A., Pochepov, V., \& Ryabychev, V. (2010). Dependence of effectiveness of development of mining operations on processibility of coal seams deposits with thickness of $1.2 \mathrm{~m}$. New Techniques and Technologies in Mining, 51-55. https://doi.org/10.1201/b11329-10

Kuz'menko, O., Petlyovanyy, M., \& Stupnik, M. (2013). The influence of fine particles of binding materials on the strength properties of hardening backfill. Annual Scientific-Technical Collection - Mining of Mineral Deposits, 45-48. https://doi.org/10.1201/b16354-10

Kuzmenko, O., Petlyovanyy, M., \& Heylo, A. (2014). Application of fine-grained binding materials in technology of hardening backfill construction. Progressive Technologies of Coal, Coalbed Methane, and Ores Mining, 465-469. https://doi.org/10.1201/b17547-79 
Lèbre, É., Corder, G.D., \& Golev, A. (2017). Sustainable practices in the management of mining waste: a focus on the mineral resource. Minerals Engineering, (107), 34-42. https://doi.org/10.1016/j.mineng.2016.12.004

Lima, A.T., Mitchell, K., O'Connell, D.W., Verhoeven, J., \& Van Cappellen, P. (2016). The legacy of surface mining: remediation, restoration, reclamation and rehabilitation. Environmental Science \& Policy, (66), 227-233.

https://doi.org/10.1016/j.envsci.2016.07.011

Liu, J., Yu, Q., Zuo, Z., Yang, F., Duan, W., \& Qin, Q. (2017). Blast furnace slag obtained from dry granulation method as a component in slag cement. Construction and Building Materials, (131), 381-387.

https://doi.org/10.1016/j.conbuildmat.2016.11.040

Lozynskyi, V., Saik, P., Petlovanyi, M., Sai, K., Malanchuk, Z. \& Malanchuk, Y. (2018). Substantiation into mass and heat balance for underground coal gasification in faulting zones. Inzynieria Mineralna, 19(2), 289-300. https://doi.org/10.29227/IM-2018-02-36

Malanchuk, Y., Moshynskyi, V., Korniienko, V., \& Malanchuk, Z. (2018). Modeling the process of hydromechanical amber extraction. E3S Web of Conferences, (60), 00005. https://doi.org/10.1051/e3sconf/20186000005

Malashkevych, D., Sotskov, V., Medyanyk, V., \& Prykhodchenko, D. (2018). Integrated evaluation of the worked-out area partial backfill effect of stress-strain state of coal-bearing rock mass. Solid State Phenomena, (277), 213-220. https://doi.org/10.4028/www.scientific.net/ssp.277.213

Mnukhin, A.G. (2009). Porodnye otvaly - syr'ye budushchego. Ugol' Ukrainy, (5), 28-32.

Natsionalna dopovid pro stan navkolyshnoho pryrodnoho seredovyshcha $v$ Ukraini u 2014 rotsi. (2014). Kyiv: Ministerstvo ekolohii ta pryrodnykh resursiv Ukrainy.

Nikolaienko, K.V., Yevtiekhov, V.D., Babets, Ye.K., Filenko, V.V., \& Petrukhin, A.V. (2012). Rozrobka tekhnolohii zbahachennia tekhnohennoi syrovyny u vyhliadi zalizovmisnykh khvostiv dlia otrymannia $\mathrm{z}$ nykh kontsentratu $\mathrm{z}$ vmistom zaliza ne menshe $65 \%$. Zbahachennia Korysnykh Kopalyn, 48(89), 168-172.

Oliinyk, T.A., \& Prokopchuk, D.S. (2016). Rozrobka kompleksnoi tekhnolohii zbahachennia shlakiv TES. Rozvytok Promyslovosti ta Suspilstva, (1), 317-318.

Paranko, I.S., Yevtiekhov, V.D., \& Sydorenko, V.D. (2007). Shliakhy vyrishennia aktualnykh problem Kryvorizkoho baseinu v umovakh staloho rozvytku rehionu. Heoloho-Mineralohichnyi Visnyk, 1(17), 5-11.

Peregudov, V.V., Gritsina, A.E., \& Dragun, B.T. (2010). Current state and future development of iron-ore industry in Ukraine. Metallurgical and Mining Industry, 2(2), 145-151.

Petlovanyi, M.V., \& Medianyk, V.Y. (2018). Assessment of coal mine waste dumps development priority. Naukovyi Visnyk Natsionalnoho Hirnychoho Universytetu, (4), 28-35. https://doi.org/10.29202/nvngu/2018-4/3

Petlovanyi, M.V., Lozynskyi, V.H., Saik, P.B., \& Sai, K.S. (2018). Modern experience of low-coal seams underground mining in Ukraine. International Journal of Mining Science and Technology, 28(6), 917-923. https://doi.org/10.1016/j.ijmst.2018.05.014

Petlovanyi, M., Lozynskyi, V., Zubko, S., Saik, P., \& Sai, K. (2019). The influence of geology and ore deposit occurrence conditions on dilution indicators of extracted reserves. Rudarsko Geolosko Naftni Zbornik, 34(1), 83-91. https://doi.org/10.17794/rgn.2019.1.8

Popovich, V.V. (2016). Phytomeliorative recovery in reduction of multi-element anomalies influence ofdevastated landscapes. Biological Bulletin of Bogdan Chmelnitskiy Melitopol State Pedagogical University, 6(1), 94-114. https://doi.org/10.15421/201606
Popovych, V., Kuzmenko, O., Voloshchyshyn, A., \& Petlovanyi, M. (2018). Influence of man-made edaphotopes of the spoil heap on biota. E3S Web of Conferences, (60), 00010. https://oi.org/10.1051/e3sconf/20186000010

Prosandieiev, M.I. (2013). Osoblyvosti tekhnohennykh rodovyshch ta deiaki pravovi aspekty yikh ekspluatatsii. Ekolohiia i Pryrodokorystuvannia, (17), 130-134.

Prybylova, V.M. (2013). Otsinka vplyvu tekhnohennoho navantazhennia na heolohichne seredovyshche ta osoblyvosti nakopychennia zabrudniuvachiv $\mathrm{V}$ zoni rozmishchennia Zmiivskoi TES (Kharkivska oblast). Visnyk Kharkivskoho Natsionalnoho Universytetu im. V.N. Karazina. Seriia: Heolohiia. Heohrafiia. Ekolohiia, (39), 237-242.

Rehionalna dopovid pro stan navkolyshnoho pryrodnoho seredovyshcha Dnipropetrovskoi oblasti za 2015 rik. (2016a). Dnipro: Departament ekolohii ta pryrodnykh resursiv Dnipropetrovskoi oblderzhadministratsii.

Rehionalna dopovid pro stan navkolyshnoho pryrodnoho seredovyshcha Donetskoi oblasti za 2015 rik. (2016b). Pokrovsk: Departament ekolohii ta pryrodnykh resursiv Donetskoi oblderzhadministratsii.

Rusina, V.V. (2007). Mineral'nye vyazhushchie veshchestva na osnove mnogotonnazhnykh promyshlennykh otkhodov. Bratsk: GOU VPO "BrGU".

Saik, P., Petlovanyi, M., Lozynskyi, V., Sai, K., \& Merzlikin, A. (2018). Innovative approach to the integrated use of energy resources of underground coal gasification. Solid State Phenomena, (277), 221-231. https://doi.org/10.4028/www.scientific.net/ssp.277.221

Shaw, R.A., Petavratzi, E., \& Bloodworth, A.J. (2013). Resource recovery from mine waste. Waste as a Resource, 44-65. https://doi.org/10.1039/9781849737883-00044

Solovey, V.V., Vorob'yeva, I.A., \& Volovina, T.V. (2006). Tekhnologiya utilizatsii zoloshlakovykh otkhodov tverdotoplivnykh elektrostantsiy. Sotrudnichestvo dlya Resheniya Problemy Otkhodov, 142-143.

Sotskov, V.O., Podvyhina, O.O., Dereviahina, N.I., \& Malashkevych, D.S. (2018). Substantiating the criteria for applying selective excavation of coal deposits in the Western Donbass. Journal of Geology, Geography and Geoecology, 26(1), 158-164.

https://doi.org/10.15421/111817

State Statistics Service of Ukraine. (2019). Retrieved from http://www.ukrstat.org

Streltsov, V., Evtekhov, V., \& Evtekhova, A. (2017). Some mineralogical zoning features of iron ore riebeckite metasomatites in the Kryvyi Rih Basin. Visnyk of Taras Shevchenko National University of Kyiv. Geology, 1(76), 52-57. https://doi.org/10.17721/1728-2713.76.08

Sun, W., Wang, H., \& Hou, K. (2018). Control of waste rocktailings paste backfill for active mining subsidence areas. Journal of Cleaner Production, (171), 567-579. https://doi.org/10.1016/j.jclepro.2017.09.253

Vilkul, Yu.G., Azaryan, A.A., \& Kolosov, V.A. (2013). Pererabotka i kompleksnoe ispol'zovanie mineral'nogo syr'ya tekhnogennykh mestorozhdeniy. Gornyy Vestnik, 1(96), 3-10.

Zhang, L., \& Xu, Z. (2018). A critical review of material flow, recycling technologies, challenges and future strategy for scattered metals from minerals to wastes. Journal of Cleaner Production, (202), 1001-1025. https://doi.org/10.1016/i.jclepro.2018.08.073

Zhukovskiy, T.F. (2010). Resursosberegayushchaya i ekologicheski orientirovannaya tekhnologiya polucheniya vanadievoy produktsii iz otkhodov proizvodstva. Visnyk Natsionalnoho Tekhnichnoho Universytetu "KhPI". Seriia: Khimiia, Khimichna Tekhnolohiia i Ekolohiia, (13), 29-35.

Zubova, L.G. (2004). Terrikoniki ugol'nykh shakht - istochnik syr'ya dlya polucheniya galliya, germaniya, vismuta. Ugol' Ukrainy, (1), 41-42. 


\section{ОГЛЯД НАКОПИЧЕННЯ І ПЕРСПЕКТИВИ РОЗРОБКИ ТЕХНОГЕННИХ УТВОРЕНЬ ГІРНИЧОПРОМИСЛОВИХ РЕГІОНІВ УКРАЇНИ}

\section{М. Петльований, О. Кузьменко, В. Лозинський, В. Попович, К. Сай, П. Саїк}

Мета. Аналіз об'ємів накопичення, місць розташування та перспектив промислової розробки техногенних утворень гірничо-металургійного й паливно-енергетичного комплексів Дніпропетровської області.

Методика. У роботі використано комплексний підхід, що включає аналіз даних державної статистики, місць видалення відходів (МВВ), регіональної доповіді про стан навколишнього середовища, екологічного паспорта регіону, а також даних інших інформаційних джерел. Аерофотознімки техногенних утворень отримані за допомогою супутникової програми Google Earth 7.1.8.

Результати. Проведено аналіз накопичення основних техногенних утворень гірничо-металургійного та паливно-енергетичного комплексів України (породні відвали вугільної й гірничорудної галузей, хвостосховища, золошлаковідвали, відвали металургійних шлаків), оцінені іх об'єми та займані площі. За найбільш щільним розташуванням техногенних утворень їх запропоновано розділити на 4 райони: Придніпровський, Криворізький, Нікопольський і Павлоградський. За даними інформаційних джерел встановлено вміст деяких цінних компонентів у різних техногенних відходах. На підставі вивчення світових ринкових цін компонентів техногенних родовищ запропоновано районувати їх за вартістю цінних компонентів у 1 т відходів. Запропоновано перспективні напрями використання мінерально-сировинних ресурсів у різних галузях економіки. Відзначено, що 3 позиції освоєння мінерально-сировинного потенціалу інтерес представляють насипні відходи в силу їх значних запасів на мінімальній площі, а з позиції охорони навколишнього середовища та інтересів українського народу - наливні техногенні відходи, що займають значні площі сільськогосподарських угідь і мають менші запаси мінеральної сировини.

Наукова новизна. Розширено та систематизовано уявлення щодо мінерально-сировинного фонду техногенної сировини Дніпропетровської області для подальшого освоєння як альтернатива природним родовищам. Вперше здійснено комплексний та детальний аналіз техногенних відходів найбільшого регіону-накопичувача України і запропоновано групування відходів гірничодобувного та енергетичного сектору за щільністю розташування й вмістом цінних компонентів.

Практична значимість. Складена схематична карта розташування техногенних відходів та проведена градація за попередньою перспективністю їх освоєння. Це дозволить більш об'єктивно підходити до концепції промислового освоєння техногенних відходів і планування стратегії розвитку мінерально-сировинного фонду на державному та регіональному рівнях.

Ключові слова: техногенні відходи та родовища, породні відвали, хвостосховища, золошлакосховища, відвали металургійних илаків, промислове освоєння, градація

\section{ОБЗОР НАКОПЛЕНИЯ И ПЕРСПЕКТИВЫ РАЗРАБОТКИ ТЕХНОГЕННЫХ ОБРАЗОВАНИЙ ГОРНОПРОМЫШЛЕННЫХ РЕГИОНОВ УКРАИНЫ}

\section{М. Петлёваный, А. Кузьменко, В. Лозинский, В. Попович, Е. Сай, П. Саик}

Цель. Анализ объемов накопления, мест расположения и перспектив промышленной разработки техногенных образований горно-металлургического и топливно-энергетического комплексов Днепропетровской области.

Методика. В работе использован комплексный подход, включающий анализ данных государственной статистики, мест удаления отходов (МУО), регионального доклада о состоянии окружающей среды, экологического паспорта региона, а также данных других информационных источников. Аэрофотоснимки техногенных образований получены с помощью спутниковой программы Google Earth 7.1.8.

Результаты. Проведен анализ накопления основный техногенных образований горно-металлургического и топливно-энергетического комплексов Украины (породные отвалы угольной и горнорудной отраслей, хвостохранилища, золошлакоотвалы, отвалы металлургических шлаков), оценены их объемы и занимаемые площади. По наиболее плотному расположению техногенных образований их предложено разделить на 4 района: Приднепровский, Криворожский, Никопольский и Павлоградский районы. По данным информационных источников установлено содержание некоторых ценных компонентов в разных техногенных отходах. На основании изучения мировых рыночных цен компонентов техногенных месторождений предложено районировать их по стоимости ценных компонентов в 1 т отходов. Предложены перспективные направления использования минерально-сырьевых ресурсов в различных отраслях экономики. Отмечено, что с позиции освоения минеральноесырьевого потенциала интерес представляют насыпные отход по причине их больших запасов на минимальной площади, а с позиции охраны окружающей среды и интересов украинского народа - наливные техногенные образования, занимающие значительные площади сельскохозяйственных угодий и имеющие меньшие запасы минерального сырья.

Научная новизна. Расширено и систематизировано представление о минерально-сырьевом фонде техногенного сырья Днепропетровской области для дальнейшего промышленного освоения как альтернатива природным месторождениям. Впервые осуществлен комплексный и детальный анализ техногенных отходов наиболее крупного региона-накопителя Украины и предложено группирование отходов горнодобывающего и энергетического сектора по плотности расположения и ценности содержащихся компонентов. 
Практическая значимость. Составлена схематическая карта размещения техногенных отходов и проведена градация по предварительной перспективности их освоения. Это позволит более объективно подходить к концепции промышленного освоения техногенных отходов и планирования стратегии развития минерально-сырьевого фонда на государственном и региональном уровнях.

Ключевые слова: техногенные отходы и месторождения, породные отвалы, хвостохранилища, золошлакохранилища, отваль металлургических илаков, промышленное освоение, градация

\section{ARTICLE INFO}

Received: 5 May 2018

Accepted: 10 January 2019

Available online: 25 January 2019

\section{ABOUT AUTHORS}

Mykhailo Petlovanyi, Candidate of Technical Sciences, Associate Professor of the Underground Mining Department, Dnipro University of Technology, 19 Yavornytskoho Ave., 49005, Dnipro, Ukraine. E-mail: petlyovany@ukr.net

Oleksandr Kuzmenko, Doctor of Technical Sciences, Professor of the Underground Mining Department, Dnipro University of Technology, 19 Yavornytskoho Ave., 49005, Dnipro, Ukraine. E-mail: kuzma-lexx@gmail.com

Vasyl Lozynskyi, Candidate of Technical Sciences, Associate Professor of the Underground Mining Department, Dnipro University of Technology, 19 Yavornytskoho Ave., 49005, Dnipro, Ukraine. E-mail: lvg.nmu@gmail.com

Vasyl Popovych, Doctor of Technical Sciences, Head of the Environmental Safety Department, Lviv State University of Life Safety, 35 Kleparivska St, 79007, Lviv, 79007, Ukraine. E-mail: popovich2007@ukr.net

Kateryna Sai, Candidate of Technical Sciences, Assistant Professor of the Underground Mining Department, Dnipro University of Technology, 19 Yavornytskoho Ave., 49005, Dnipro, Ukraine. E-mail: kateryna.sai@gmail.com

Pavlo Saik, Candidate of Technical Sciences, Associate Professor of the Underground Mining Department, Dnipro University of Technology, 19 Yavornytskoho Ave., 49005, Dnipro, Ukraine. E-mail: saik.nmu@gmail.com 